\title{
Intestine Disease Diagnosis System Using Certainty Factor Method
}

\author{
Chandra Kirana ${ }^{1}$, Harrizkie Arie Pradana ${ }^{2}$, Rahmat Sulaiman ${ }^{3}$ \\ ${ }^{1,2,3}$ Information Technology, STMIK Atma Luhur Pangkalpinang \\ Email: ${ }^{1}$ chandra.kirana@atmaluhur.ac.id, ${ }^{2}$ harrizkiariep@atmaluhur.ac.id, \\ ${ }^{3}$ rahmatsulaiman@atmaluhur.ac.id
}

\begin{abstract}
Inside the human body there are many important organs, one of which is the intestine. Intestinal disease / digestive disease is a disease that most often attacks the digestive tract in humans. There are several intestinal diseases that are dangerous and there are also harmless intestinal diseases. In this research, researchers created an android-based expert system application that can provide information to the users about diseases that are being suffered through the symptoms experienced by the user. The process of making expert system applications using the certainty factor algorithm. The certainty factor algorithm is used to accommodate the uncertainty of an expert's. The mechanism that be used in the certainty factor algorithm on each symptom uses a measure of increased belief (MB) and measure of increased disbelief (MD). Expert system applications that have been built to detect intestinal diseases based on Android have been successfully implemented with a presentation of accuracy of $99.7265625 \%$. by that percentage, it show us that the diagnosis of symptoms of the selected disease is in suitable by the experienced of user, and has the accuracy determined by the system.
\end{abstract}

Keywords: Expert System, Certainty Factor Algorithm, Intestinal Disease

\section{INTRODUCTION}

Inside the human body there are many important organs, one of which is the intestine. Intestinal disease / digestive disease is a disease that occurs in the digestive tract of the human intestine. Diseases of the digestive tract are dangerous diseases and cause many deaths. Often times people are lazy to consult with a doctor because the queue is long or busy by their job.

Expert systems follow the behavior of an expert in dealing with a problem. There is one case a patient comes to a doctor to check his body for health problems, the doctor will examine and make a diagnosis. If the doctor is busy, the implementation of the diagnosis will be replaced by an expert system. The main 
objective of expert systems is not to replace the position of an expert, but for the knowledge and the experience of experts who are experts in their fields [1]. Therefore, the existence of an expert system is to be expected to help people suffering from diseases, especially in the stomach, to check their own symptoms using an android smartphone without having to wait for the queue or interfere with their working hours.

Artificial intelligence is part of computer science that makes machines (computers) able to work like humans. Intelligent systems are systems that are built by using artificial intelligence techniques. One of many expert systems are learned in artificial intelligence is using the Certainty Factor Method.

Certainty Factor (CF) is "Amount that reflects the level of trust in the Hypothesis of existing information". The factors of the symptoms of the diseases will be calculated by the CF method, so that an accurate type of complaint will be obtained. As its implementation by utilizing an equipment namely Mobile such as a smartphone, gadget [2]. Research on intestinal disease is very necessary to prevent the occurrence of death caused by lazy people to conduct consultations.

The expected benefits from this research is an information on the diseases suffered by users when they are sick and can be used as material information, references, articles and archives as a benchmark.

Research related to intelligent systems including the research conducted are:

1. Diagnosis of Ornamental Plant Disease Using Web-Based Certainty Factor Method to produce an application to diagnose diseases of ornamental plants [3].

2. Expert System to Diagnose Cholesterol in Adolescents with Web-Based Certainty Factor (CF) Method" resulted in an application for diagnosing cholesterol disease [4].

3. Application of the Certainty Factor Method in Osteoporosis and Osteoarthritis Risk Detection Expert Systems" produced an application for the diagnosis of osteoporosis and osteoarthritis [5].

4. Expert System for Diagnosing Pregnant Women Using the Certainty Factor (CF) Method [6].

5. Mental Disorders in Children with the Certainty Factor Method resulted in an application that can determine mental disorders in children using the certainty factor method [7].

6. Case-Based Reasoning for Diagnosis of ENT (Ear Nose and Throat) resulted in a case-based reasoning system for diagnosing ENT disease [8].

7. Case-Based Reasoning for the Diagnosis of Heart Disease" resulted in a system capable of recognizing heart disease [9].

8. An Expert System Using Certainty Factor for Insomnia Acupoint Determination. This research produces acupuncture points based on symptoms from patients who experience insomnia [10]. 


\section{METHODS}

\subsection{Problem Analysis}

A disease that attacks the intestine is a disease that we need to be aware of because it can cause death for someone from the effects of the intestinal illness itself. At present, there are still many patients who are reluctant to do consultations due to remote places and a very long consultation process. The consultation process starts from the registration, and then after the registration process is complete, the waiting process is queued. After that, a consultation process with the doctor was only carried out and finally the drug collection process. From these processes, there are still weaknesses including the process of consulting with doctors requires a long time if the queue process is long so that the delay in handling patients.

From the problems that have been explaining, an expert system is needed that can help doctors deal with patient complaints quickly. Through the expert system, patients can find out what diseases are suffered based on symptoms that have been experiencing. Figure 1 below is an architecture of expert systems.

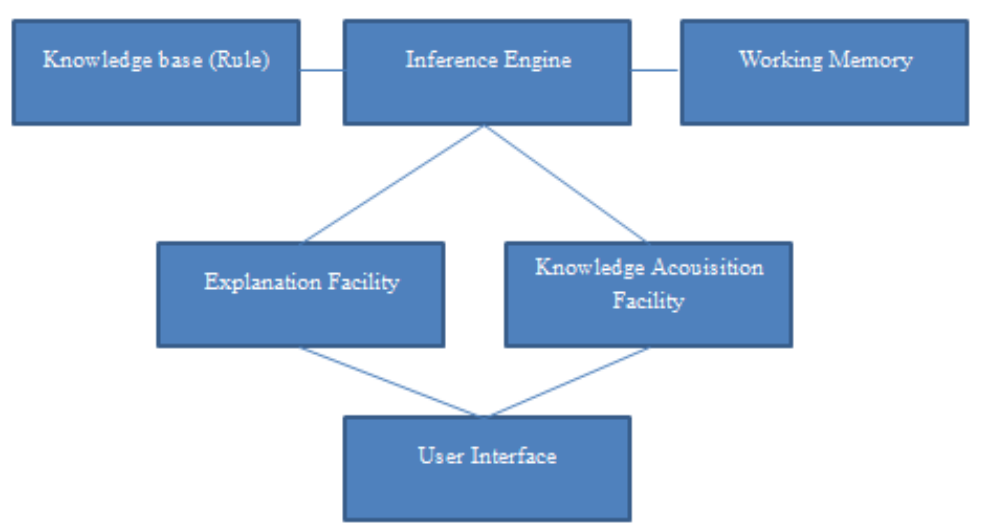

Figure 1. Expert Systems Architecture [11]

\subsection{Certainty Factor Method}

The Certainty Factor method is a method that is used to calculate the certainty factor in determining the symptoms and types of diseases suffered by users.

\subsubsection{Determined the Combined Certainty Factor}

Certainty Factor is the final Certainty Factor of a prospective conclusion. Combined CF is the last CF of a candidate conclusion. This CF is influencing by all parallel CFs of the rules that produce the outcome. If different symptoms cause the same disease, then it is included in the general certainty factor equation. 
For example, in symptom $G(G 1, G 2 \ldots G n)$ creates disease $P$, then there is a value $E(E 1, E 2, \ldots ., E n)$ that also causes disease $P$, there are values $C F 1(P, G)$ and $\mathrm{CF} 2(\mathrm{P}, \mathrm{G})$. The level of certainty produced by the system in determining the diagnosis is CF combination as formulated in equation (1) [6].

$$
\mathrm{CF} \text { combination }[\mathrm{CF} 1, \mathrm{CF} 2]=\mathrm{CF} 1+\mathrm{CF} 2 *(1-\mathrm{CF} 1)
$$

The advantages of this Joint Certainty Factor are suitable for expert systems that measure something definite or uncertain such as diagnosing disease, and the calculation of this method is only valid for one count, and can only process two data so that accuracy is maintaining.

\subsection{Intestinal Diagnosis Expert Systems}

The steps for calculating the Certainty Factor shown in Figure 2. The first step is to calculate the value of CF (E) based on symptom data, by reducing Measure of Belief (MB) and Measure of Disbelief (MD) which is the expert value of a symptom of an illness. After calculating the amount of CF (E), then do the calculation using the $\mathrm{CF}$ formula combination to get the value of each rule. The process of diagnosing intestinal disease shown in Figure 3.

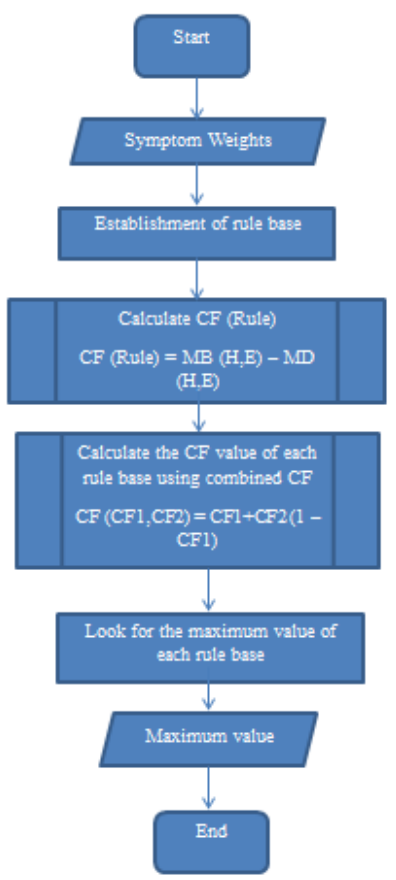

Figure 2. Certainty Factor Measurement Flowchart 


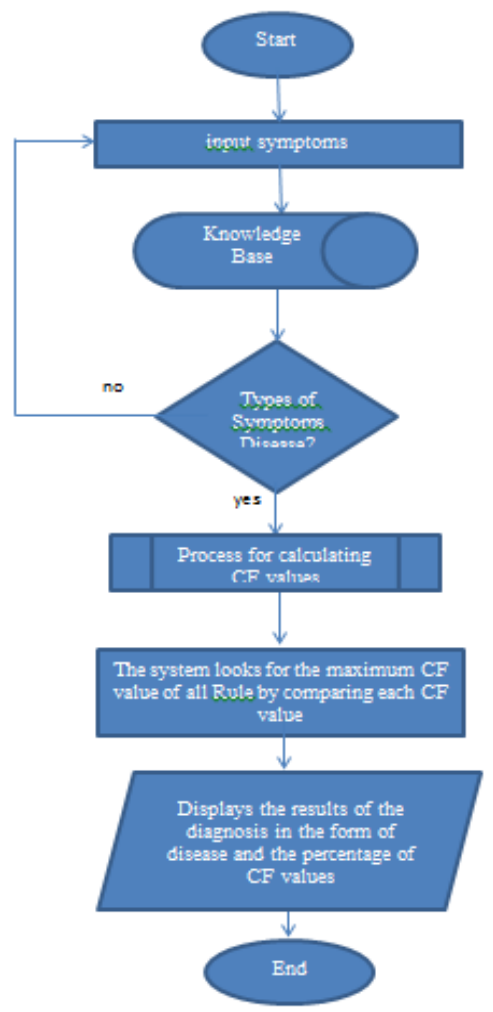

Figure 3. Diagnosis Systems Flowchart with Certainty Factor

\subsection{Analysis of Calculation of the Certainty Factor Method}

Certainty Factor (Rule) value is generating from an interpretation (term) of an expert, where the amount is changing to a specific $\mathrm{CF}$ value according to table 1 .

Table 1. Certainty Factor's Value

\begin{tabular}{|c|c|c|c|c|c|c|c|c|c|}
\hline $\begin{array}{c}\text { CF } \\
\text { Value }\end{array}$ & -1.0 & -0.8 & -0.6 & -0.4 & $\begin{array}{c}-0.2 \text { to } \\
0.2\end{array}$ & 0.4 & 0.6 & 0.8 & 1.0 \\
\hline $\begin{array}{l}\text { Uncer } \\
\text { tain } \\
\text { Term }\end{array}$ & $\begin{array}{l}\text { Definitely } \\
\text { Not }\end{array}$ & $\begin{array}{l}\text { Almost } \\
\text { Certain } \\
\text { Not }\end{array}$ & $\begin{array}{l}\text { Probably } \\
\text { Nnot }\end{array}$ & $\begin{array}{l}\text { Maybe } \\
\text { Not }\end{array}$ & Unknown & Maybe & Probably & $\begin{array}{l}\text { Almost } \\
\text { Certainty }\end{array}$ & Definitely \\
\hline
\end{tabular}

In the expert system, the process of diagnosing symptoms of an intestinal disease is represented using predetermined production rules. The rules of diagnosis in this expert system can be seen in Table 2 while the percentage of conclusions shown in Table 3.

Table 2. List of Disease Diagnosis Rule 


\begin{tabular}{ll}
\hline ID & Rule \\
\hline 1. & IF Mushy and Slushy \\
& AND Continously to the toilet \\
& AND nauseous and vomit \\
& AND loss of appetite \\
& AND fever \\
& AND stomach cramps \\
& AND stomache \\
& AND bloody sfeces \\
& AND many kind of Feces \\
& THEN diarrhea \\
2. IF stomach cramps and bloated \\
AND difficult to defecate \\
AND distended stomach \\
AND feels like there's feces left after defecate \\
AND stomache \\
THEN constipation \\
IF bloody when defecate \\
AND lump in the anus \\
AND feces come by it's own \\
AND mucous come around the anus \\
AND iritate around the anus \\
THEN Hemoroid \\
IF stomach bloated \\
AND cant fart \\
AND diarrhea \\
AND nauseous and vomit \\
AND fever \\
THEN appendicitis \\
IF pain around stomatch \\
AND loss of appetite \\
AND body weight decrease significantly \\
AND bloody diarrhea \\
THEN colitis \\
\hline
\end{tabular}

Table 3. The Interpretation List of Disease Diagnosis Rule

\begin{tabular}{ccl}
\hline No. & Percentage Level & \multicolumn{1}{c}{ Certainty Value } \\
\hline 1 & $0 \%-50 \%$ & Small Possibility \\
2 & $51 \%-79 \%$ & Certainly \\
3 & $80 \%-99 \%$ & Most Likely \\
4 & $100 \%$ & Very Sure \\
\hline
\end{tabular}

\subsubsection{Example calculation of the Certainty Factor Method.}

In this example, a patient experiences several symptoms which shown in Table 4. 
Table 4. Symptoms and Disease

\begin{tabular}{clcc}
\hline No. & \multicolumn{1}{c}{ Symptoms of diarrhea } & Diarrhea & Blind Gut \\
\hline 1 & Soft and Runny Stool & 0.6 & 0 \\
2 & Stomach ache & 0.6 & 0 \\
3 & Abdominal cramps & 0.4 & 0 \\
4 & Nausea and vomiting & 0.2 & 0.6 \\
5 & Loss of appetite & 0.4 & 0 \\
6 & Fever & 0.4 & 0.6 \\
7 & Blood in the stool & 0.6 & 0 \\
8 & A lot of stool is produced & 0.6 & 0 \\
9 & Continuously to the toilet & 0.6 & 0 \\
10 & Bloated & 0 & 0.6 \\
11 & Cannot dispose of fart & 0 & 0.6 \\
12 & Constipation or diarrhea & 0 & 0.4 \\
\hline
\end{tabular}

From Table 4 can be seen where the symptoms already have expert weights will be calculated and will produce a diagnosis of the disease by the data selected by the patient. Following is the calculation of the Symptom Certainty Factor method shown in Table 4.

1. Diarrheal Disease

IF Soft and Runny Stool

AND Continuously to the toilet

AND Nausea and vomiting

AND Loss of appetite

AND Fever

AND Abdominal cramps

AND Stomach ache

AND Blood in the stool

AND A lot of stool is produced

THEN diarrhea

Then the calculation is as follows:

CFcombination $\mathrm{CF} 1,2=\mathrm{CF} 1+\mathrm{CF} 2 *(1-\mathrm{CF} 1)=0.6+0.6 *(1-0.6)=0.6+$ $0.24=0.84$

Result $\mathrm{CF}=0.84$

CFcombination CF $=$ Result CF + CF3 * $(1-$ Result CF $)=0.84+0.4 *(1-$ $0.84)=0.84+0.064=0.904$

Result $\mathrm{CF}=0.904$

CFcombination $\mathrm{CF}=$ Result $\mathrm{CF}+\mathrm{CF} 4 *(1-$ Result $\mathrm{CF})=0.904+0.2 *(1-$ $0.904)=0.904+0.0192=0.9232$

Result $\mathrm{CF}=0.9232$

CFcombination CF $=$ Result CF + CF5 * (1-Result CF $)=0.9232+0.4 *(1-$ $0.9232)=0.9232+0.03072=0.95392$

Result $\mathrm{CF}=0.95392$ 
CFcombination CF $=$ Result CF + CF6 * $(1-$ Result CF $)=0.95392+0.4 *(1-$ $0.95392)=0.95392+0.018432=0.972352$

Result CF $=0.972352$

CFcombination $\mathrm{CF}=$ Result $\mathrm{CF}+\mathrm{CF} 7 *(1-$ Result $\mathrm{CF})=0.972352+0.6$ * $(1-0.972352)=0.972352+0.0165888=0.9889408$

Result $\mathrm{CF}=0.9889408$

CFcombination CF= Result CF + CF8 * (1- Result CF $)=0.9889408+0.6$ * $(1-0.9889408)=0.9889408+0.00663552=0.99557632$

Result $\mathrm{CF}=0.99557632$

CFcombination $\mathrm{CF}=$ Result CF + CF9 * $(1-$ Result CF $)=0.99557632+0.6$

$*(1-0.99557632)=0.99557632+0.002654208=0.998230528$

Result CF $=\mathbf{0 . 9 9 8 2 3 0 5 2 8}$

Then the CF value of the symptoms chosen for the diarrheal disease is likely to be $\mathbf{9 9 . 8 2 \%}$.

2. Appendicitis

IF Bloated

AND Cannot dispose of fart

AND Constipation or diarrhea

AND Nausea and vomiting

AND Fever

THEN Appendix

Then the calculation is as follows:

CFcombination $\mathrm{CF} 1,2=\mathrm{CF} 1+\mathrm{CF} 2 *(1-\mathrm{CF} 1)=0.6+0.6 *(1-0.6)=0.6+$ $0.24=0.84$

Result $\mathrm{CF}=0.84$

CFcombination $\mathrm{CF}=$ Result $\mathrm{CF}+\mathrm{CF} 3 *(1-$ Result $\mathrm{CF})=0.84+0.4 *(1-$ $0.84)=0.84+0.064=0.904$

Result $\mathrm{CF}=0.904$

CFcombination $\mathrm{CF}=$ Result $\mathrm{CF}+\mathrm{CF} 4 *(1-$ Result $\mathrm{CF})=0.904+0.6 *(1-$ $0.904)=0.904+0.0576=0.9616$

Result $\mathrm{CF}=0.9616$

CFcombination CF $=$ Result CF + CF5 * $(1-$ Result CF $)=0.9616+0.6 *(1-$ $0.9616)=0.9616+0.02304=0.98464$

Result $\mathrm{CF}=\mathbf{0 . 9 8 4 6 4}$

Then the CF value of the selected symptoms for appendicitis is probably $\mathbf{9 8 . 4 6 \%}$.

Based on calculations carried out using the Certainty Factor method for each 
disease, the maximum CF value of $99.82 \%$ is obtaining with a diagnosis of Diarrhea, so it is concluding that by patients suffering from Diarrhea.

\subsection{Knowledge Representation}

Knowledge representation in this research is carrying out after the knowledge acquisition process has been carried out. Knowledge representation is carried out with the aim of developing a structure that will help the process of coding knowledge into a system that is building. Knowledge representation is carried out using the production rules [10].

\subsection{Usecase Diagram}

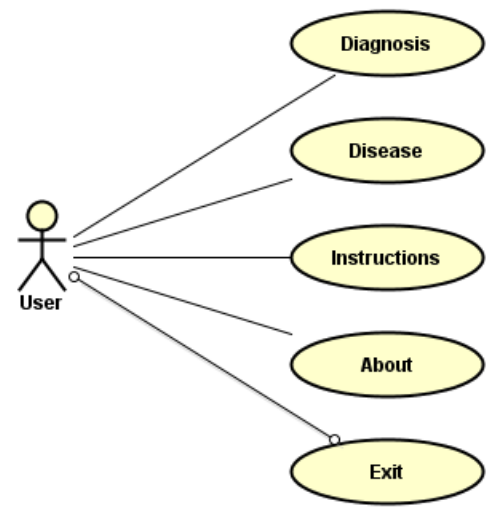

Figure 4. Proposal System Usecase Diagram

Figure 4 explains how a user can use the application that being build. The claim that is growing has several menus, including the diagnosis of diseases suffered by patients, disease menus, application usage instructions, about applications.

\subsection{Class Diagram}

Class Diagram of an Android-based intestinal disease expert system application with the Certainty Factor method shown in Figure 5. 


\begin{tabular}{|c|c|c|}
\hline symptoms & & disease \\
\hline $\begin{array}{l}\text { - id_symptoms0 : char } \\
\text { - name of symptoms : char }\end{array}$ & & $\begin{array}{l}\text { - id_disease : char } \\
\text { - name of disease : char }\end{array}$ \\
\hline $\begin{array}{l}\text { + add } 0: \text { void } \\
+ \text { edit } 0: \text { void } \\
\text { + delete } 0: \text { void }\end{array}$ & * * & $\begin{array}{l}\text { + add } 0: \text { void } \\
+ \text { edit } 0: \text { void } \\
\text { + delete } 0: \text { void }\end{array}$ \\
\hline
\end{tabular}

\begin{tabular}{|l|}
\hline \multicolumn{1}{|c|}{ knowledge } \\
\hline - id_knowledge : int \\
- id_disease : char \\
- id_symptoms : char \\
- $\mathrm{mb}:$ double \\
- $\mathrm{md}:$ double \\
\hline
\end{tabular}

\begin{tabular}{|l|}
\hline \multicolumn{1}{|c|}{ admin } \\
\hline - usemame : char \\
- password : char \\
- admin role : char \\
- information : char \\
\hline + add $0:$ void \\
+ edit $0:$ void \\
+ delete $0:$ void \\
\hline
\end{tabular}

Figure 5. Class Diagram

\section{RESULT AND DISCUSSION}

\subsection{Application Main Page}

This main page is the initial display of an expert system application for diagnosing intestinal diseases. On this page there are several menus including diagnosis, disease, application usage instructions, about the form and also the exit menu.

\subsection{Diagnosis Page}

This diagnostic page displays the symptoms suffered by the patient by checking the signs suffered. If it has finished, the application will display the disease experienced by the patient based on the symptoms that have to choose.

\subsection{Testing}

Testing in this study the author refers to ISO 25010 which has eight characteristics, namely functional suitability, reliability, performance efficiency, usability, security, compatibility, maintainability, and portability. From the eight components, the writer uses four characters, namely Usability, Performance Efficiency, Portability, and Functional Suitability.

a. Usability testing

This test uses a questionnaire method with many respondents as many as 30 people consisting of 10 lecturers, 18 students, and two doctor assistants. Before filling out the questionnaire, the respondents are required to try the application that has been making in advance. From the results of the survey, 
the percentage is $93.33 \%$ so that it can be concluding that the form that has been build can be applied.

b. Performance Efficiency Testing

This test uses tools Testdroid. With this tool can be seen concerning memory usage and CPU. Testing is done using several devices that are available on Testdroid tools including Google Pixel 9.0, LG Google Nexus 5 6.0.1, LG Google Nexus 5 D820 5.0. The results of performance efficiency testing using tools Testdroid can be seeing that memory usage is still quite safe so there is no memory leak, while CPU usage can be seeing that the average user is in the safe category.
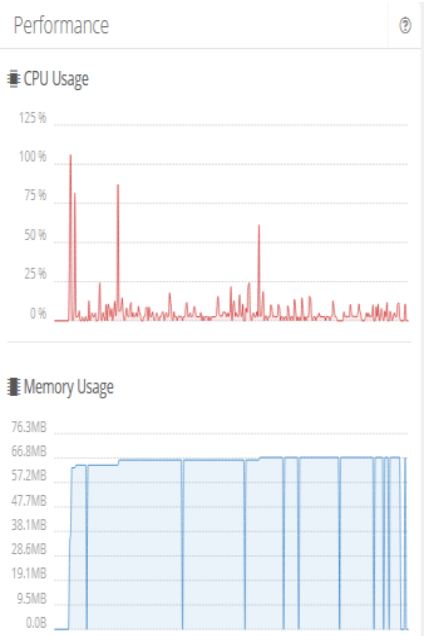

Figure 6(a) Google Pixel 9.0 Device
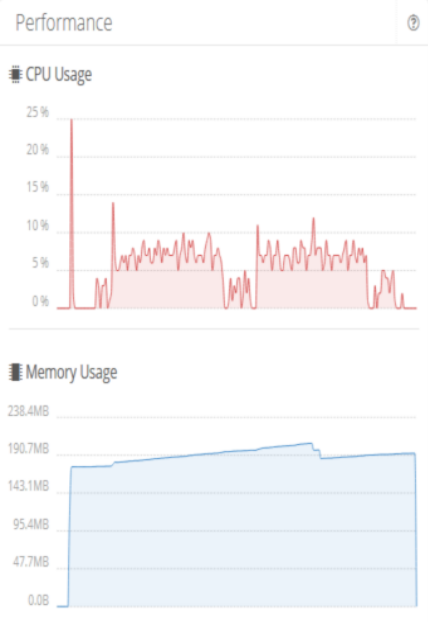

Figure 6(b) LG Google Nexus 5 6.0.1 Device
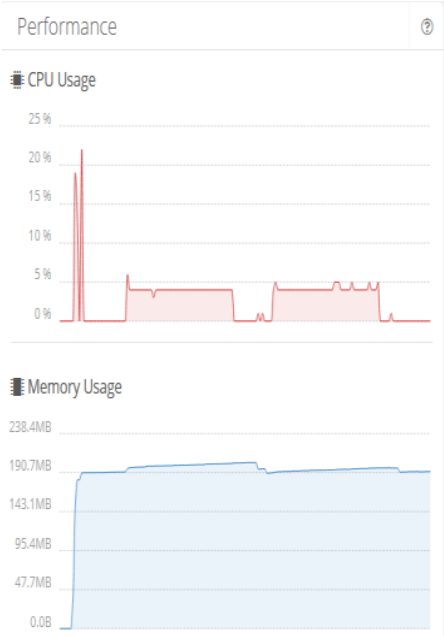

Figure 6(c) LG Google Nexus 5 D820 5.0 Device

Figure 6. Application Performance Testing

c. Portability Testing

This test was done by trying several smartphones with different Android operating systems, including marshmallow, nougat, and KitKat. From the results of tests carried out stating that the applications that have been build can be installed and can run properly. 
Table 5. Portability Aspects Result

\begin{tabular}{ccccl}
\hline No. & Device Type(s) & Android Type(s) & $\begin{array}{c}\text { Installation } \\
\text { Process }\end{array}$ & $\begin{array}{c}\text { Application Process } \\
\text { Running }\end{array}$ \\
\hline 1 & Xiaomi Redmi Note 4 & 6.0 (Marshmallow) & Success & Running without an error \\
2 & Xiaomi Redmi 4X & 7.0 (Nougat) & Success & Running without an error \\
3 & Samsung Tab 3 & 4.4 (KitKat) & Success & Running without an error \\
\hline
\end{tabular}

\section{d. Functional Suitability Testing}

This test uses a questionnaire method that is giving to 2 people, according to the author of an expert in the field of software engineering. Before giving results, the application is tried to run first, so based on table 3 that the attribute functionality makes the request.

\section{Table 6. Functional Suitability Testing Table}

\begin{tabular}{ccl}
\hline Testing Activities & Testing Results & Information \\
\hline Click the Diagnose Menu & A diagnose form appears & Success \\
Click the Process Button & Calculation appears as a result of selecting & Success \\
Click the Disease Menu & symptoms. & Success \\
Click the Instructions Menu & Disease form appears. & Success \\
Click the About Menu & Appearance form appears. & Success \\
\hline
\end{tabular}

\section{CONCLUSION}

Based on the research and description described above, it can be concluding that the application of the Certainty Factor method can be used to recognize intestinal diseases with an accuracy rate of $\mathbf{9 9 . 8 2 \%}$.

\section{REFERENCES}

[1] Saputra, A. (2011). Sistem Pakar Identifikasi Penyakit Paru-Paru Pada manusia Menggunakan Metode Certainty Factor. Jurnal teknologi dan Informatika, 1(3), 202-222.

[2] Riwayanto, N.I. (2012). Kehamilan Berdasarkan Tingkat Certainty Factor Berbasis Android. Universitas Pembangunan Nasional (VETERAN).

[3] Mujilahwati, S. (2014). Diagnosa Penyakit Tanaman Hias Menggunakan Metode Certainty Factor Berbasis WEB. Jurnal Teknika, 6(2).

[4] Sihotang, H.T. (2014). Sistem Pakar Mendiagnosa Penyakit Kolesterol Pada Remaja Dengan Metode Certainty Factor (Cf) Berbasis Web. Jurnal Mantik Penusa, 15(1), 16-23. 
[5] Halim, S., \& Hansun, S. (2016). Penerapan Metode Certainty Factor dalam Sistem Pakar Pendeteksi Resiko Osteoporosis dan Osteoarthritis. Jurnal Ultima Computing, 7(2).

[6] Aji, A.H., Furqon, M.T., \& Widodo, A.W. (2018). Sistem Pakar Diagnosa Penyakit Ibu Hamil Menggunakan Metode Certainty Factor (CF). Jurnal Pengembangan Teknologi Informasi dan Ilmu Komputer, 2(5), 2127-2134.

[7] Susanto, C. (2015). Application of Expert System for Mental Disorders in Children with Certainty Factor. Jurnal Pekommas, 18(1), 27-36.

[8] Tedy Rismawan, S.H. (2013). Case-Based Reasoning Untuk Diagnosa Penyakit THT (Telinga Hidung dan Tenggorokan). IJCCS-Indonesian J. Comput., 6, 67-78.

[9] Wahyudi, E., \& Hartati, S. (2017). Case-Based Reasoning untuk Diagnosis Penyakit Jantung. IJCCS (Indonesian Journal Computing Cybernetics System)., 11(1), 1.

[10] Gunawan, E.P., \& Wardoyo, R. (2018). An Expert System Using Certainty Factor for Determining Insomnia Acupoint. IJCCS (Indonesian Journal Computing Cybernetics System), 12(2), 119.

[11] Giarratono, J., \& Riley, G. (2005). Expert System: Principles and Programming, 4th ed. Boston: Course Technology.

[12] Rumaisa, F., \& Junaedi, D. (2016). Expert System For Early Diagnosis Of Meningitis Disease Using Certainty Factor Method. International Conference Technology Systems and Innovation (ICITISI). BandungBali.

[13] Astuti, I., Sutarno, H., \& Rasim. (2017). The Expert SYstem Of Children's Digestive Tract Disease Diagnostic using Combination of Forward Chaining and Certainty Factor Methods. 3rd International Conferences on Science in information Technology (ICSITech). Universitas Pendidikan Indonesia.

[14] Agustina, E., Pratomo, I., Wibawa, A.D., \& Rahayu, S. (2017). Expert System for Diagnosis Pests and Diseases of The Rice Plant using Forward Chaining and Certainty Factor Method. International Seminar on Intelligent Technology and Its Application. Institut Teknologi Sepuluh Nopember. 